\title{
Hornyák Veronika
}

\section{Spanyolország fegyveres erói és a COVID-19 járvány}

DOI 10.17047/HADTUD.2021.31.2.75

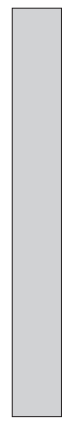

A világ egyik legnagyobb múltra visszatekintó hadereje, a spanyol fegyveres erók 2020 márciusa óta aktív szerepvállalója a COVID-19 járvány elleni védekezésnek Spanyolországban, ahol már több mint 50000 ember vesztette életét a pandémia következtében. Más uniós tagállamokhoz hasonlóan a spanyol vezetés is különleges jogrend bevezetésével, kijárási korlátozással, valamint minden idók legnagyobb békeidóben zajló belföldi katonai múveletével próbált felülkerekedni a járványügyi helyzeten. Jelen tanulmány ezen tények, tényezók kontextusában kívánja feltárni a spanyol fegyveres erók bevetésének körülményeit a COVID-19 járvány elleni védekezésben a 2020-as évben, köztük a Balmis-múvelet, valamint a Baluarte-misszió legfontosabb jellemzóit.

KULCSSZAVAK: Spanyolország, spanyol haderô, COVID-19 járvány, Balmis-múvelet, Baluarte-misszió

\section{The Spanish armed forces and the COVID-19 epidemic}

The Spanish armed forces, which is currently one of the oldest in the world, have had an active role in the fight against COVID-19 since March 2020 in Spain, where 50,000 people lost their lives due to the pandemic. Similarly to other EU members, the Spanish government has intended to overcome the crisis with the introduction of state of emergency, curfews, and the biggest domestic military operation of the nation's history. In the context of these facts and factors, the present study seeks to explore the circumstances of the deployment of the Spanish Armed Forces in the fight against the COVID-19 epidemic in 2020, including the most important characteristics of Operation Balmis and Mission Baluarte.

KEYWORDS: Spain, Spanish armed forces, COVID-19 pandemic, Operation Balmis, Mission Baluarte

\footnotetext{
^ิ Nemzeti Közszolgálati Egyetem, Hadtudományi és Honvédtisztképző Kar National University of Public Service, Doctoral School of Military Sciences; e-mail: veronika.vhornyak@gmail.com; https://orcid.org/000-0002-7344-3561
} 


\section{Bevezetés}

A COVID-19 járvány az elsô távoli hírek felröppenését követóen kevesebb mint 60 nap alatt elérte, majd 2020 tavaszán néhány hét alatt térde kényszerítette Európát. Eddig hivatalosan ismeretlen okokból a Mediterráneum két legnagyobb európai országát, Olaszországot és Spanyolországot az átlagosnál hamarabb és súlyosabban érintette a vírus, különös tekintettel annak elsó hullámára. A tradicionálisan nagy katonai hagyományokkal rendelkezô Spanyolország 2020 márciusában, az uniós nemzetek közül az egyik legszigorúbb kijárási tilalommal és korlátozásokkal válaszolt a COVID-19 kitörésére, mely hozzávetólegesen 50000 áldozatot követelt az országban a járvány kitörésének évében. ${ }^{1}$ Ezen, uniós viszonylatban magas szám egyik lehetséges oka - Olaszországhoz hasonlóan -, hogy a 47 milliós lakosság közel 20\%-a 65 év feletti, akik körében - a vírussal való megfertôzódést követóen - jóval magasabb a halálozási arány. ${ }^{2}$ A járványra válaszként a kormányzat különleges jogrendi szabályokat léptetett életbe az országban. A járvány második hulláma az elsóhöz képest arányaiban nem követelt kiugróan sok áldozatot Spanyolországban más európai országokkal összevetve, azonban a 2020 tavaszi események alapvetően határozták meg a járvánnyal kapcsolatos spanyol hozzáállást, valamint a spanyol kormányzat haderónek szánt szerepét a pandémia elleni védekezésben.

Spanyolország vonatkozó törvényi szabályozása ${ }^{3}$ a fegyveres erók szerepét egyik különleges jogrendi helyzet alkalmazásakor sem részletezi specifikusan, így a haderó bevetésének körülményei a mindenkori politikai vezetés, a kormány döntésein alapszanak. Ez utóbbi történt a koronavírus járvány kitörése okán is. A Pedro Sánchez miniszterelnök vezette adminisztráció a WHO 2020. március 11-i bejelentését követően - mikor is világjárványnak minôsítette a COVID-19-et ${ }^{4}$ - néhány napon belül elrendelte a különleges jogrend bevezetését. 2020. március 14-én királyi dekrétumban hirdették ki a riadóhelyzetet, melynek másnapján - éppen akkor, mikor a magyar kormány bejelentette az iskolák határozatlan idejú bezárását - megindították az Operación Balmis-t, vagyis a Balmis-múveletet. ${ }^{5}$ A spanyol fegyveres erók ${ }^{6}$ (a továbbiakban: FAS) belföldi, járvány elleni védekezésre történő bevetése az ország

1 Statista: Número total de personas fallecidas a causa del coronavirus en España entre el 6 de marzo y el 4 de diciembre de 2020.

https:/es.statista.com/estadisticas/1104277/fallecidos-a-causa-de-covid-19-por-dia-espana/

2 CIA: The World Factbook: Spain. 2021.

https://www.cia.gov/library/publications/the-world-factbook/geos/sp.html

3 Ley Orgánica 4/1981 de 1 día de junio de los estados de alarma, excepción y sitio [1981. évi 4. számú organikus törvény a különleges jogrendról].

https://www.defensa.gob.es/Galerias/defensadocs/LO-4-1981-estados-alarma.pdf

4 World Health Organization: WHO Director-General's opening remarks at the media briefing on COVID-19. 2020.03.11.

https://www.who.int/director-general/speeches/detail/who-director-general-s-opening-remarks -at-the-media-briefing-on-covid-19-11-march-2020

5 Ministerio de Defensa [Spanyol Védelmi Minisztérium] Reportajes: En primera línea. 2020. 03. 15. https://ejercito.defensa.gob.es/reportajes/2020/97_operacion_balmis.html

6 Fuerzas Armadas de España. 
történetének legnagyobb eddigi olyan múvelete volt, amely nemzeti határokon belül zajlott békeidóben. A múveletben minden haderőnem részt vett, azzal az alapvetô feladattal, hogy biztosítsák és segítsék a járvány elleni küzdelmet, többek között járórözéssel, illetve - a magyarországi helyzethez hasonlóan - a kórházak, a járványügyi veszélyhelyzethez szorosan kapcsolódó infrastruktúra biztosításával, védelmével, fertótlenítésével. ${ }^{7}$

Jelen tanulmány célja a jogszabályi háttér, a különleges jogrendre, valamint a haderơre, annak bevetésére vonatkozó rendelkezés(ek) vizsgálatát követóen, a napi, eredeti és idegen nyelven megjelenó sajtóforrások, valamint a spanyol kormányzat, védelmi tárca kommunikációja, kiadványai alapján összefoglalni, hogy a haderónek milyen szerep jutott a járvány elleni védekezés első évében. Emellett szintén felhasználásra kerültek a rendelkezésre álló kvantitatív adatok is, a járvánnyal kapcsolatos statisztikák, a Balmis-múvelet és az azt követô Baluarte-misszió számszerú adatai. Ez alapján tehát jelen tanulmány alapvetôen leíró-elemző módszertannal, elsődleges és másodlagos források feldolgozásával kívánja megvizsgálni a spanyol járványhelyzet sajátosságait. Az összefoglaló fejezet ismerteti, hogy a járványügyi védekezésben részt vevó, belföldi intézkedések során bevetett spanyol haderố alkalmazásával kapcsolatosan milyen változások történtek, milyen következtetések vonhatók le, illetve fejlesztési irányokat fogalmazhatóak meg.

\section{A spanyol haderó és a különleges jogrend}

Spanyolország hadereje mind európai, mind pedig világszinten is a globális, de legalábbis az uniós élvonalban foglal helyet elsôsorban több évszázados hagyományainak köszönhetốen. ${ }^{8}$ Így van ez továbbra is annak ellenére, hogy a NATO-tag uniós tagállamok közül csak Spanyolország és Olaszország GDP arányos védelmi költségvetése csökkent az elmúlt években. ${ }^{9}$ A spanyol fegyveres erók feladatát és rendeltetését az 1978. évi alkotmány 8. cikkelye rögzíti, mely alapján a FAS célja megvédeni a spanyol állam "területi integritását és az alkotmányos rendet" ${ }^{10}$ Múködésének feltételeit a továbbiakban számos törvény - például a katonák jogállásáról szóló 2011. évi 9. számú11 - és egyéb jogszabály, királyi dekrétum, kormányrendelet, illetve védelmi miniszteri rendelet rögzíti. ${ }^{12}$ Ezek közül kiemelendő a 2006. évi 416. számú királyi dekrétum (2006/04/11) a Szárazföldi Erók, a Haditengerészet, a Légieró és a Katonai Vészhelyzeti Egység ${ }^{13}$ (továbbiakban: UME) szervezetéról és

7 Ministerio de Defensa: Reportajes: En primera línea. 2020.

8 Ministerio de Defensa: Ejército de Tierra. 2021. https:/www.defensa.gob.es/fuerzasarmadas/et/\#

9 The Military Balance: Volume 120, International Institute for Strategic Studies, 2020, 70.

10 La Constitución Española, 1978. [Spanyolország alkotmánya, 1978]. https://www.lamoncloa.gob.es/documents/constitucion_es1.pdf

11 Ley Orgánica 9/2011, de 27 de julio, de derechos y deberes de los miembros de las Fuerzas Armadas.[2011. évi 9. számú organikus törvény (2011/07/27) a fegyveres erók kötelékébe tartozók jogairól és kötelezettségeiról] https://www.boe.es/buscar/pdf/2011/BOE-A-2011-12961-consolidado.pdf

12 Ejército de Tierra [Szárazföldi Erók]: Legislación. 2021. https://ejercito.defensa.gob.es/personal/legislacion_basica_defensa.html

13 Unidad Militar de Emergencias. 
bevetéséról. ${ }^{14}$ Szintén érdemes pár szóban említeni a 2017-ben elfogadott Spanyol Nemzeti Biztonsági Stratégia kapcsolódó részeit, mely az előző spanyol kormányzat, azaz Mariano Rajoy miniszterelnöksége alatt született meg. ${ }^{15}$ A dokumentum nem közvetlen fenyegetésként, hanem az ennél kisebb kockázati kategóriába sorolt kihívás kifejezéssel tesz említést a járványügyi helyzetekról, pandémiákról, mint a spanyol nemzeti biztonságra hatással levő kockázati faktorról. A stratégia hangsúlyozza, hogy a járványügyi, közegészséget veszélyeztetó kihívások - fóleg az ország turisztikai vonzereje miatt - egyre növekvő figyelmet és fokozott (fel)készültséget érdemelnek. ${ }^{16}$ Mindazonáltal egy esetleges pandémia okán bekövetkezó veszélyhelyzet esetében nem szól a fegyveres erók bevetésének lehetóségeiról. Többek között ezt a hiányosságot pótolva, valamint közvetlenül a járványhelyzetre reagálva született meg 2020-ban a spanyol Nemzeti Védelmi Irányelv, ${ }^{17}$ mely a FAS bevetéséról az alábbiak szerint ír: "A haderô állandóan fejleszti misszióit és müveleteit, rendszeresen együttmúködve és segitve a civil hatóságokat abban, hogy megküzdjenek a sok esetben nem konvencionális fenyegetésekkel" ${ }^{18}$ Az idézett rész csupán egy a védelmi irányelv számos pontja közül, melyet egyrészt közvetlenül a COVID-19 járványra reflektálva, másrészt pedig már a Balmis-múvelet tanulságait integrálva fogalmaztak meg. Az irányelv kiemelt figyelmet szentel a haderố polgári hatóságokkal, lakossággal és egyéb civil szereplókkel való együttmúködésére, ezirányú kapacitásainak fejlesztésére. ${ }^{19}$

A spanyol jogrendszerben a veszélyhelyzet esetén - demokratikus deficittel ugyan, de a magyarországi szabályozáshoz hasonlóan -, a mindenkori vezetésnek lehetôsége van különleges jogrend kihirdetésére, a rendes törvényalkotási, döntéshozatali eljárás egyszerúsítésével és lerövidítésével, hogy gyorsan tudjon reagálni az országot ért vagy fenyegetó veszélyhelyzetekre. Spanyolországban az ezen esetekre vonatkozó rendelkezéseket alapvetóen két jogszabály determinálja: az 1978-as alkotmány, ${ }^{20}$ valamint az 1981. évi 4. számú organikus törvény, ${ }^{21}$ mely a magyarországi jogszabályi hierarchia szerint a sarkalatos törvényi szintnek felel meg. Spanyolországban háromféle különleges jogrendtípust különböztetnek meg: riadóhelyzet (estado de alarma - state alarm), ${ }^{22}$ statárium (estado de sitio - state of siege), veszélyhelyzet (estado de exepción - state emergency). ${ }^{23}$

14 Real Decreto 416/2006, de 11 de abril, por el que se establece la organización y el despliegue de la Fuerza del Ejército de Tierra, de la Armada y del Ejército del Aire, así como de la Unidad Militar de Emergencias. [2006. évi 416. számú királyi dekrétum (2006/04/11) a Szárazföldi Erók, a Haditengerészet, a Légieró és a Katonai Vészhelyzeti Egység szervezetéról és bevetéséról]. https://www.boe.es/buscar/act.php?id=BOE-A-2006-7168

15 Spanish National Security Strategy [Spanyol Nemzeti Biztonsági Stratégia]. 2017. https://www.dsn.gob.es/sites/dsn/files/2017_Spanish_National_Security_Strategy_0.pdf

16 Spanish National Security Strategy, 74.

17 Presidencia de Gobierno [Miniszterelnökség]: Directiva de la Defensa Nacional 2020. https://www.defensa.gob.es/Galerias/defensadocs/directiva-defensa-nacional-2020.pdf

18 Uo. 5-6.

19 Uo. 6.

20 Constitución Española, 1978.

21 Ley Orgánica 4/1981 de 1 día de junio de los estados de alarma, excepción y sitio.

22 Presidencia del Gobierno: Estado de Alarma. 2020. https://www.lamoncloa.gob.es/covid-19/Paginas/estado-de-alarma.aspx

23 Ley Orgánica 4/1981 de 1 día de junio de los estados de alarma, excepción y sitio. 
A fentiekben felvázolt elméleti-jogi keretben múködő spanyol haderó - hivatalos nevén az Állami Védelmi Erók vagy Védelmi Törzs (EMAD) ${ }^{24}$ - fóparancsnoka ${ }^{25}$ az államfő, a spanyol uralkodó, jelenleg VI. Fülöp spanyol király, míg a polgári irányítást a mindenkori kormányon keresztül a Védelmi Minisztérium élén álló tárcavezetô miniszter látja el. A haderố civil kontrolljáért is felelós védelmi miniszter 2018 óta Margarita Robles Fernández. ${ }^{26}$ A fegyveres erók vezérkari főnöke - mely beosztás Spanyolországban államtitkári pozícióval azonos szintet jelent az államigazgatásban - 2020 januárja óta a spanyol haditengerészet tábornoka, Teodoro E. López Calderón vezérezredes. ${ }^{27}$

A spanyol haderó sajátossága, hogy a három klasszikus haderónem, a légieró, a haditengerészet, valamint a szárazföldi erók jelenlétén túl, külön a fegyveres erók összhaderónemi formában múködő egységeként tartják számon a Királyi (Test-)Ôrséget - eredeti nevén Guardia Real -, valamint a már említett Katonai Vészhelyzeti Egységet (UME). ${ }^{28}$ Ami a rendelkezésre álló katonai állományt illeti, a Védelmi Minisztérium által 2019-ben közétett hivatalos statisztika szerint a spanyol haderô összesen 145417 fót számlált, melyból 120102 fó teljesített aktív szolgálatot. ${ }^{29}$ A spanyol rendszer érdekessége, hogy a fegyveres erók állományát kiegészíti a katonai kötelmi viszonyok szerint múködó, de rendvédelmi feladatokat ellátó Guardia Civil, azaz a Csendórség, melyben több mint 80000 egyenruhás szolgál a tartalékos állománnyal együtt. ${ }^{30}$ A Csendôrség jogállásának és rendeltetésének kettôsségét az adja, hogy a személyi állománya felett csak a katonai missziók esetében rendelkezik a Védelmi Minisztérium, minden más esetben a Belügyminisztérium az illetékes irányító szerv. ${ }^{31}$

Az ENSZ Biztonsági Tanács 1325. számú, a nók, béke és biztonság határozat ${ }^{32}$ elfogadásának 20. évfordulója éppen a COVID-19 járvány kitörésével egy évre esett, melynek kapcsán érdemes pár szóban kitérni a nemek arányára, nók szerepére a spanyol fegyveres eróknél. A külföldi szakirodalomban „women, peace and security”, röviden WPS agendaként ${ }^{33}$ hivatkozott témakörre tárcaközi együttmúködés keretében - a biztonsági-védelmi aspektust és a haderóvel kapcsolatos kérdéseket prioritásként kezelve - kiemelt figyelmet fordít a spanyol kormányzat. ${ }^{34}$ Emellett említésre

24 Estado Mayor de la Defensa.

25 Jefe del Estado de la Defensa (JEMAD).

26 Ministerio de Defensa: organigrama. 2020. https:/www.defensa.gob.es/ministerio/organigrama/

27 Estado Mayor de la Defensa: Jefe de Estado Mayor de la Defensa. 2021. https://emad.defensa.gob.es/emad/?_locale =es

28 Ministerio de Defensa: Unidad Militar de Emergencia. 2020. https:/www.defensa.gob.es/ume/CONOCENOS/que-es/

29 Ministerio de Defensa: Estadística de Personal Militar de Carrera de las FAS. 2019. 19. https://publicaciones.defensa.gob.es/media/downloadable/files/links/e/s/estad_stica_de_personal _militar_de_carrera_2019.pdf

30 Uo. 9.

31 Guardia Civil: 2021. https:/www.guardiacivil.es/es/institucional/Conocenos/index.html

32 United Nations Security Council Resolution 1325 (2000) on women, peace and security. https://www.un.org/womenwatch/osagi/wps/

33 Uo.

34 Gobierno de España [Spanyolország Kormánya]: Mujeres, Paz y Seguridad:

Por una agenda eficaz y sostenida. 2019. https://www.dsn.gob.es/sites /dsn/files/MUJERES\% 2C\% 20PAZ\%20Y\%20SEGURIDAD\% 20\% 28WEB\% 29.pdf 
méltó, hogy Spanyolország azon államok közé tartozik, ahol nem elôször tölti be nó a védelmi miniszteri pozíciót. A fegyveres erók tekintetében teljes állomány 6,2\%-a nó, mely arány haderônemenként, illetve az egyes alakulatoknál hozzávetólegesen 3-8\% között mozog. A spanyol Védelmi Minisztérium 2019-es hivatalos adatai alapján a katonanók aránya a szárazföldi haderônem esetében a legalacsonyabb, mindösszesen 3,1\%, míg a Csendőrség, valamint a Katonai Vészhelyzeti Egység esetében a legmagasabb, azonban itt sem haladja meg a 8\%-ot, mely az európai áltagnál jóval alacsonyabb arány. ${ }^{35}$

\section{A Balmis-múvelet és a Baluarte-misszió: Spanyolország a COVID-19 ellen}

A COVID-19 járvány elsố hulláma Spanyolországot - valószínúsíthetôen az olasz-spanyol lakosság közötti szoros kapcsolat és sokszoros kapcsolódási pontok miatt is - az elsók között, már 2020 február végén elérte. Az olasz események láttán a Pedro Sánchez vezette spanyol kormányzat, a növekvő esetszámokkal párhuzamosan, 2020 márciusának első́ napjaiban elrendelte az első szigorításokat. Ennek nyomán ki hirdették ki elsóként a riadóhelyzetet, majd 2020. március 15-én és kezdetét vette a fegyveres erók járvány elleni védekezésének megszervezésére és lebonyolítására az Ibériai-félszigeten minden idók legnagyobb, békeidóben az államhatárokon belül zajló múvelete, a Balmis-múvelet, ${ }^{36}$ amely összesen 98 napig tartott, s 2020. június 20 -án zárult. ${ }^{37}$ A spanyol haderó ezen idő alatt több mint 20000 beavatkozást hajtott végre a múvelet részeként, melynek több mint fele - összesen 11000 esetben - fertôzött helyszínek fertőtlenítését jelentette. Ebból 5000 esetben a feladatot idôsek otthonában, 3500 alkalommal pedig kórházakban kellett ellátni a Balmis-múveletben részt vevő katonáknak. ${ }^{38}$ A fegyveres erók állománya az ország összes tartományában, összesen több mint 2300 helyszínen segítette a vírus elleni védekezést. ${ }^{39}$ A Balmis-múveletben - mely a 19. század elején szolgáló, tengerentúli humanitárius expedíciót vezetô katonaorvosról, Francisco Javier Balmisról kapta a nevét - legnagyobb százalékban az UME kötelékébe tartozó katonák képviseltették magukat. ${ }^{40}$ Ennek oka, hogy a 2005-ben létrehozott különleges „haderónem” elsődleges feladata a természeti katasztrófák és egyéb, a civil lakosságot veszélyeztetô esetekben, a kifejezetten belföldön történó beavatkozás, segítségnyújtás, azaz katasztrófavédelmi

35 Ministerio de Defensa. 2019, 55.

36 European Parliament: The role of armed forces in the fight against coronavirus. 2020. https://www.europarl.europa.eu/RegData/etudes/BRIE/2020/649401/EPRS_BRI(2020)649401_EN.pdf 3.o.

37 infodefensa.com: Las cifras de la Operación Balmis: 20.000 intervenciónes en 98 días de lucha 2020. https://www.infodefensa.com/es/2020/06/27/noticia-cifras-operacion-balmis-20000-intervenciones -lucha.html

38 infodefensa.com. 2020.

39 Uo.

40 Estado Mayor de la Defensa: Operation 'Balmis' deploys more than 2.500 troops in 172 cities to control COVID-19. 2020.

https://emad.defensa.gob.es/en/prensa/noticias/2020/03/listado/200324-Continuacion -Operacion-Balmis.html 
feladatok ellátása. ${ }^{41}$ A járványügyi statisztikákkal párhuzamosan, a haderô legnagyobb arányú mozgósítása 2020. április hónapjára tehető, mikor a Balmis-múveletben napi szinten 5000 egyenruhás teljesített szolgálatot Spanyolországban, azaz látott el feladatokat a járvány elleni védekezés részeként. ${ }^{42} \mathrm{~A}$ Spanyol Védelmi Minisztérium által kiadott információk alapján a Balmis-múveletben részt vevố egyenruhások 43\%-a az UME, 36\%-a a szárazföldi erók, 16\%-a a haditengerészet, $5 \%$-a pedig a légieró kötelékéból került ki, mely adatokat az 1. ábra hivatott szemlélteti. ${ }^{43}$

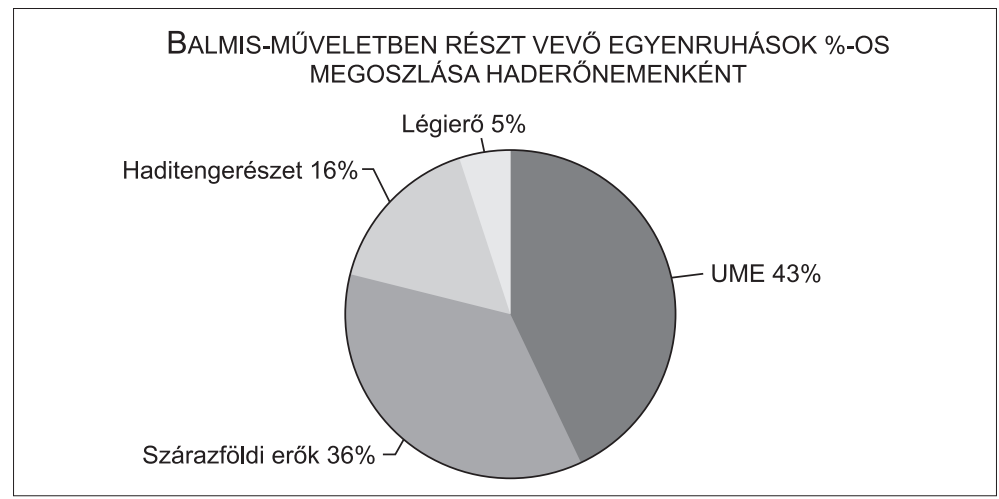

1. ábra.

Balmis-múveletben részt vevố egyenruhások százalékos megoszlása haderónemenként

(A szerző saját szerkesztése.)

(Forrás: Estado Mayor de la Defensa (2020) Las Fuerzas Armadas cumplen dos meses de lucha contra la COVID-19. https://emad.defensa.gob.es/prensa/noticias/2020/05/listado/200518-balance-balmis.html?_locale=es)

A Balmis-múvelet befejeztével és a nyár végi nyugodtabb időszakot követóen, 2020 ốszén a COVID-19 járvány második hulláma is elérte Európát. Ahogy más uniós tagállamokban, a karantén utáni nyitást követôen a társadalom félelme a vírustól Spanyolországban is alábbhagyott a nyári hónapokban, ezzel egyidóben a több havi bezártságból adódó frusztráció miatt az érintkezési szabályok betartása, betartatása egyre nagyobb problémát jelentett. Ezzel párhuzamosan, illetve ebból kifolyólag vette kezdetét 2020. szeptember 11-én a spanyol haderó újabb bevetése a COVID-19 elleni védekezés jegyében, a Baluarte-misszióo. ${ }^{44}$ 2020. október 24-én ismételten elrendelték a különleges jogrend egyik esetét, a riadóhelyzetet, mely a tavaszi járványügyi intézkedésekhez képest enyhébb szabályozásokat tartalmaz, azonban idóben

41 Ministerio de Defensa. Unidad Militar de Emergencia. 2020.

42 infodefensa.com. 2020.

43 Estado Mayor de la Defensa: Las Fuerzas Armadas cumplen dos meses de lucha contra la COVID-19. 2020.

https://emad.defensa.gob.es/prensa/noticias/2020/05/listado/200518-balance-balmis.html?_locale=es

44 Revista Española de Defensa: Misión Baluarte: una defensa contra el COVID-19.

Ministerio de Defensa 2020.

https://www.defensa.gob.es/Galerias/gabinete/red/2020/10/p-6-13-red-376-rastreadores.pdf, 8.o. 
annál jóval tartósabb. ${ }^{45}$ A 2020. október 26-i héten 15 napra kihirdette a kormány a riadóhelyzetet, melyet néhány nappal késóbb a törvényhozásért felelős kongresszus jóváhagyásával hat hónapos idótartamra, egészen 2021. május 9-ig meghosszabbítottak. ${ }^{46}$ Az alkotmány által biztosított különleges jogrend ezen formájában többek között éjszakai kijárási tilalmat rendeltek el 23.00-06.00 óra között Spanyolország minden tartományában, a Kanári-szigeteket kivéve. ${ }^{47}$

A Baluarte-misszió a Balmis-múvelethez képest jóval korlátozottabb kapacitásokat, emberállományt vesz igénybe, hiszen csupán néhány ezer fó részvételével zajlik, illetve elsósorban és szinte kizárólagosan nem fegyveres szolgálatteljesítésre alapszik. Ebben a jelenlegi helyzetben a Baluarte-misszió során kivezényelt szárazföldi erók, az UME, a haditengerészet, valamint a légieró kötelékébe tartozó egyenruhások feladata egy olyan kommunikációs központ múködtetése a tartományi kormányzatokkal együttmúködve, mely folyamatosan monitorozza és detektálja a (lehetséges) fertózötteket. ${ }^{48} 2021$. január 6-ig bezárólag a Baluarte-misszió keretében összesen 750000 vizsgálatot hajtottak végre koronavírus-fertôzés gyanúja miatt 2400 fő egyenruhás bevetésével. ${ }^{49}$ A jelenlegi járványügyi helyzetben, 2021 januárjában tehát a fegyveres erók bevetése a COVID-19 elleni védekezésre elsősorban a Baluarte-misszió keretei között zajlik, azonban emellett az UME - mint elsódleges katasztrófavédelmi feladatokat ellátó katonai szervezet - továbbra is napi szinten vesz részt olyan feladatokban, mint fertótlenítések, valamint a járvány következtében elhunyt állampolgárok holttesteinek elszállítása.

Érdemes azonban más megvilágításba helyezve is megvizsgálni a fegyveres erók COVID-19 járvány elleni bevetésének mérlegét, hiszen azt nem csupán a spanyolországi járványügyi védekezés volumene, statisztikái határozzák meg. A közel 100 napos, belföldi Balmis-múvelet során például elótérbe, illetve felszínre került számos olyan, a spanyol haderóben jelen levô probléma, mely békeidóben kevésbé volt a szakmai és politikai figyelem kereszttüzében. Az egyenruhásoknak nem csupán magával a vírussal és annak társadalmi hatásaival kellett szembenézni, de olyan, a munkavégzést, feladatteljesítést nehezítő tényezókkel, mint a belföldi utazási korlátozások, a befagyasztott bérek, infrastrukturális és egyéb, például ellátáshoz kapcsolódó hiányosságok. ${ }^{50}$ A járvány váratlansága és súlyossága tehát próbára tette nem csupán az egészégügyi és közigazgatási rendszert, hanem a belbiztonság és védelempolitika számos aspektusát, többek között a haderô parancsnoki-irányítási rendszerét is.

45 El País: España, en alarma: el Gobierno busca que dure hasta mayo y decreta toque de queda. 2020. https:/elpais.com/espana/2020-10-25/sanchez-aprueba-un-nuevo-estado-de-alarma-para-toda -espana-con-intencion-de-que-se-prolongue-hasta-el-9-de-mayo.html

46 Presidencia del Gobierno. Estado de Alarma. 2020.

47 Uo.

48 Revista Española de Defensa. Misión Baluarte: una defensa contra el COVID-19. 2020. 8.o.

49 Ministerio de Defensa: Discurso de la Ministra de Defensa en la Pascua Militar. 2021. 3. https://www.defensa.gob.es/Galerias/gabinete/ficheros_docs/2021/Discurso_Pascua_Militar _Ministra_de_Defensa_2021.pdf

50 European Organisation of Military Associations and Trade Unions: Armed forces and COVID-19. 2020. http://euromil.org/armed-forces-and-covid-19/ 
Ezzel párhuzamosan a gyarmatosítás, valamint a Franco-diktatúra (1936-1975) katonai hagyományaitól a 21. században sok esetben szándékosan elhatárolódni kívánó spanyol társadalom ismét szembe találta magát az egyenruhás katonák látványával Spanyolország utcáin. A COVID-19 elleni védekezés jegyében folyó múvelet és misszió során a FAS katonáinak munkája, erófeszítései napi szinten láthatóvá, kézzel foghatóvá váltak a spanyol lakosság számára. A Baluarte-misszióban a kommunikációs központ múködtetésében részt vevő, a szárazföldi haderónemhez tartozó altiszt elmondása alapján a lakossággal való telefonos kapcsolattartás során az esetek döntô többségében pozitívan reagálnak a egyenruhások megkeresésére az állampolgárok: "nagyon jól fogadják, mikor említjük, hogy katonák vagyunk". ${ }^{1}$ A járvány elleni védekezés tehát a fegyveres erók polgári lakossággal való érintkezése, általában a civil-katonai kapcsolatok, valamint a társadalom fegyveres erókhöz való viszonya tekintetében számos lehetôséget adott eddig és tartogat hosszútávon is Spanyolország számára. Szintén remek példája ennek a COVID-19 elleni beavatkozások és a Balmis-múvelet indítása után a védekezés jelmondatává vált frázis az „Este vírus lo paramos unidos”, vagyis „Ezt a vírust közösen állítjuk meg” használata, melyet a Védelmi Minisztréium és a fegyveres erók intézkedéseinek népszerúsítésére, társadalommal való megismertetésére is használtak. ${ }^{52}$ Az egyik legnépszerúbb tartalommegosztó közösségi média applikáción, az Instagramon például több mint 220000 esetben töltöttek fel olyan képanyagot vagy videófelvételt, melynél megemlítették, használták ezt a jelmondatot. ${ }^{53}$ Ez csupán egy apró, mégis szemléletes példa a modern technológia, a társadalom és a haderó közötti kapcsolódási pontokra, melyek hatást gyakoroltak a spanyol civil-katonai kapcsolatokra közvetlenül az egyenruhások járvány elleni védekezésének nyomán.

\section{Tanulságok és további készültség: mi történik a járvány kitörése után egy évvel Spanyolországban?}

A COVID-19 járvány elleni védekezés katonai aspektusait Spanyolországban a Balmis-múvelet és a Baluarte-misszió határozta meg a járvány elsó évében. Míg az elsó egy rövidebb, de volumenében, feladatszintú összetettségében és intenzitásában is példa nélküli katonai múveletként aposztrofálható a spanyol történelemben békeidóben, addig a Baluarte-misszió a feladatokat jóval szúkebb körben meghatározva, azonban hosszú távon biztosítja a fegyveres erók bevetésének lehetôségét a járvány elleni védekezésben. 2021 elsó heteiben a spanyol vezetés és tartományi kormányzatok a járvány harmadik hullámára készülve a májusig kihirdetett általános szabályok szigorítása mellett döntöttek. ${ }^{54}$ A kijárási tilalom meghosszabbítása, a maszkviselési

51 Revista Española de Defensa. Misión Baluarte: una defensa contra el COVID-19. 2020. 8.

52 Revista Española de Defensa: Operación Balmis - Mision: Salvar Vidas. Ministerio de Defensa, 2020. https://www.defensa.gob.es/Galerias/gabinete/red/2020/05/RED372.pdf

53 Instagram: \# estevirusloparamosunidos 2021. https://www.instagram.com/explore/tags/estevirusloparamosunidos/

54 El País: Toques de queda adelantados, reducción de horarios, cierres: las comunidades endurecen medidas ante el coronavirus. 2021.

https://elpais.com/sociedad/2021-01-15/toques-de-queda-adelantados-reduccion-de-horarios-cierres -las-duras-medidas-de-las-comunidades-ante-el-coronavirus.html 
szabályok szigorítása, valamint a vendéglátóipari egységek nyitvatartási idejének korlátozása mind-mind azt sugallják, hogy a spanyolok lassan egy évvel a járvány kitörését követôen ismételten a korlátozások kibővítését és a folyamatos készenlétet priorizálják. Ez utóbbiak a fegyveres erók tekintetében a 2021-es évben akár újabb változásokat, valamint a COVID-19 elsó hulláma során zajló Balmis-múvelet tanulságaiból adódó elsősorban civil-katonai, infrastrukturális és szervezeti jellegú haderófejlesztést eredményezhetnek.

Végezetül érdemes meghatározni néhány fontos, a statisztikai és egyéb számadatokon felüli, a haderô COVID-19 járvánnyal kapcsolatos szerepvállalása kapcsán kiemelt jelentőségú tényezót. A haderő különleges jogrendben békeidóben való bevetése, különös tekintettel a Balmis-múveletre rávilágított a fegyveres erók jelenlegi állománya, az infrastruktúra és a szervezetrendszer hiányosságaira, amelyeken felül egy másik fontos tényezô is a vizsgálódás középpontjába került: a civil-katonai kapcsolatok, a haderố társadalmi láthatósága és az egyenruhásokhoz való társadalmi attitûd kérdése. A pandémia a fegyveres eróket láthatóvá, a katonákat és munkájukat pedig kézzel foghatóvá tette az állampolgárok számára egy olyan országban, ahol a Franco-diktatúra miatt továbbra is sokan az elnyomó hatalom jelképeként tekintettek a haderốre, az egyenruhásokra. Ahogyan egy, a járványügyi védekezésben részt vevő, a légierô kötelékében szolgáló hadnagy fogalmazott: „Megengedték, hogy közeledjünk a társadalomhoz, hogy láthatóvá tegyük magunkat." ${ }^{55} \mathrm{~A}$ spanyol fegyveres erók bevetése a járvány elleni védekezésben tehát több szempontból is a szakma, a katonai hivatás javára válhat a jövóben, hiszen egyrészt alkalmas volt arra, hogy a katonákkal kapcsolatos problémákat a felszínre hozza. Ez többek között elósegítheti a spanyol egyenruhások munkakörülményeinek, nyugdíjazásának, valamint általános elismertségének előmozdítását, fejlődését. Másrészrôl pedig haderôfejlesztési szempontból is jelentôs lehet, hiszen többek között a Balmis-múvelet leginkább kézzel fogható eredményeként született meg a 2020 májusában kiadott királyi dekrétum, ${ }^{56}$ mely a 2017 -es Spanyol Nemzeti Biztonsági Stratégia, illetve a 2020-as Nemzeti Védelmi Irányelvek alapján, amely a pandémia elleni védekezés tapasztalatait felhasználva igyekszik modernizálni és aktualizálni a fegyveres erók felépítését, alkalmazásának céljait és prioritásait. A járvány elleni védekezés és a civil-katonai kapcsolatok elótérbe kerülése mellett ismételten fókuszba került, illetve tovább erôsödött a szakmai párbeszéd a nók spanyol fegyveres erókben való szerepvállalása, a katonanók számának növelése iránti igény terén. ${ }^{57}$

55 Fernando, Cancio: Militares contra el coronavirus: “Al servicio de los españoles". La Razón 2020/10/11. https://www.larazon.es/espana/20201011/x4gt3ww37bgunezvlt6vzfitfa.html

56 Real Decreto 521/2020, de 19 de mayo, por el que se establece la organización básica de las Fuerzas Armadas. [2020. évi 521. számú királyi dekrétum (2020/05/19) a fegyveres erók alapvetó felépítéséról]. https://www.defensa.gob.es/Galerias/ministerio/organigramadocs/RD-521-2020-organizacion

-basica-fuerzas-armadas.pdf

57 A kézirat lezárásának dátuma: 2021. február 1. 


\section{FELHASZNÁLT IRODALOM}

Cancio, Fernando 2020. Militares contra el coronavirus: "Al servicio de los españoles". La Razón 2020/10/11. https://www.larazon.es/espana/20201011/x4gt3ww37bgunezvlt6vzfitfa.html (Letöltés dátuma: 2020. 11. 04.)

CIA The World Factbook: Spain. 2021. https://www.cia.gov/library/publications/the-world-factbook/geos/sp.html (Letöltés dátuma: 2020. 11. 20.)

Constitución Española: 1978. https://www.lamoncloa.gob.es/documents/constitucion_es1.pdf (Letöltés dátuma: 2020. 11. 04.)

Ejército de Tierra: Legislación. 2021. https://ejercito.defensa.gob.es/personal/legislacion_basica_defensa.html (Letöltés dátuma: 2020. 11. 04.)

El País: España, en alarma: el Gobierno busca que dure hasta mayo y decreta toque de queda. 2020. https://elpais.com/espana/2020-10-25/sanchez-aprueba-un-nuevo-estado-de-alarma-para -toda-espana-con-intencion-de-que-se-prolongue-hasta-el-9-de-mayo.html (Letöltés dátuma: 2020. 11. 04.)

El País: Toques de queda adelantados, reducción de horarios, cierres: las comunidades endurecen medidas ante el coronavirus. 2021.

https://elpais.com/sociedad/2021-01-15/toques-de-queda-adelantados-reduccion -de-horarios-cierres-las-duras-medidas-de-las-comunidades-ante-el-coronavirus.html (Letöltés dátuma: 2021. 01. 15.)

Estado Mayor de la Defensa: Las Fuerzas Armadas cumplen dos meses de lucha contra la COVID-19. 2020. https://emad.defensa.gob.es/prensa/noticias/2020/05/listado/200518-balance-balmis.html? __locale =es (Letöltés dátuma: 2020. 11. 04.)

Estado Mayor de la Defensa: Operation 'Balmis' deploys more than 2.500 troops in 172 cities to control COVID-19. 2020. https://emad.defensa.gob.es/en/prensa/noticias /2020/03/listado/200324-Continuacion-Operacion-Balmis.html (Letöltés dátuma: 2020.11.04.)

European Organisation of Military Associations and Trade Unions: Armed forces and COVID-19. 2020. http://euromil.org/armed-forces-and-covid-19/ (Letöltés dátuma: 2020. 10. 20.)

European Parliament: The role of armed forces in the fight against coronavirus. 2020. https://www.europarl.europa.eu/RegData/etudes/BRIE/2020/649401/EPRS_BRI(2020)649401_EN.pdf (Letöltés dátuma: 2020.10.20.)

Gobierno de España: Mujeres, Paz y Seguridad: Por una agenda eficaz y sostenida. 2019. https://www.dsn.gob.es/sites/dsn/files/MUJERES\%2C\%20PAZ\%20Y\%20SEGURIDAD\% 20 \%28WEB\% 29.pdf (Letöltés dátuma: 2020. 10. 20.)

Guardia Civil: 2020. https://www.guardiacivil.es/es/institucional/Conocenos/index.html (Letöltés dátuma: 2021. 01. 15.)

Infodefensa.com: Las cifras de la Operación Balmis: 20.000 intervenciónes en 98 días de lucha. 2020. https://www.infodefensa.com/es/2020/06/27/noticia-cifras-operacion-balmis-20000 -intervenciones-lucha.html (Letöltés dátuma: 2020. 11. 03.)

Instagram: \# estevirusloparamosunidos. 2021. https://www.instagram.com/explore/tags/estevirusloparamosunidos/

International Institute for Strategic Studies: The Military Balance 2020. Routledge, London. 2020.

Ley Orgánica 4/1981 de 1 día de junio de los estados de alarma, excepción y sitio https://www.defensa.gob.es/Galerias/defensadocs/LO-4-1981-estados-alarma.pdf (Letöltés dátuma: 2020. 11. 04.)

Ley Orgánica 9/2011, de 27 de julio, de derechos y deberes de los miembros de las Fuerzas Armadas https://www.boe.es/buscar/pdf/2011/BOE-A-2011-12961-consolidado.pdf (Letöltés dátuma: 2020. 11. 29.)

Ministerio de Defensa: Ejército de Tierra. 2020. https://www.defensa.gob.es/fuerzasarmadas/et/\# (Letöltés dátuma: 2020. 11. 04.)

Ministerio de Defensa: Estadística de Personal Militar de Carrera de las FAS. 2019. https://publicaciones.defensa.gob.es/media/downloadable/files/links/e/s/estad_stica _de_personal_militar_de_carrera_2019.pdf (Letöltés dátuma: 2020. 11. 04.) 
Ministerio de Defensa: Estado Mayor de la Defensa. 2020

https://www.defensa.gob.es/fuerzasarmadas/emad/ (Letöltés dátuma: 2020. 11. 04.)

Ministerio de Defensa: Unidad Militar de Emergencia - Quienes somos. 2020 https://www.defensa.gob.es/ume/CONOCENOS/que-es/ (Letöltés dátuma: 2020. 12. 01.)

Ministerio de Defensa: En primera línea. Reportajes 15/03/2020. 2020 https://ejercito.defensa.gob.es/reportajes/2020/97_operacion_balmis.html (Letöltés dátuma: 2020. 10. 20.)

Ministerio de Defensa: Estado de alarma, excepción y sitio. 2020 https://www.defensa.gob.es/defensa/cadenamando/situaciones/ (Letöltés dátuma: 2020. 11. 04.)

Ministerio de Defensa: organigrama. 2020/e. https://www.defensa.gob.es/ministerio/organigrama/ (Letöltés dátuma: 2020. 11. 04.)

Ministerio de Defensa: Directiva de la Defensa Nacional. 2020. https://www.defensa.gob.es/Galerias/defensadocs/directiva-defensa-nacional-2020.pdf (Letöltés dátuma: 2020. 11. 04.)

Ministerio de Defensa: Discurso de la Ministra de Defensa en la Pascua Militar. 2021. https://www.defensa.gob.es/Galerias/gabinete/ficheros_docs/2021/Discurso_Pascua_Militar _Ministra_de_Defensa_2021.pdf (Letöltés dátuma: 2021. 01. 05.)

Presidencia del Gobierno: Estado de Alarma. 2020. https://www.lamoncloa.gob.es/covid-19/Paginas/estado-de-alarma.aspx (Letöltés dátuma: 2020. 12. 05.)

Real Decreto 416/2006, de 11 de abril, por el que se establece la organización y el despliegue de la Fuerza del Ejército de Tierra, de la Armada y del Ejército del Aire, así como de la Unidad Militar de Emergencias. https://www.boe.es/buscar/act.php?id=BOE-A-2006-7168 (Letöltés dátuma: 2020. 05. 21.)

Real Decreto 521/2020, de 19 de mayo, por el que se establece la organización básica de las Fuerzas Armadas. https:/www.defensa.gob.es/Galerias/ministerio/organigramadocs/RD-521-2020-organizacion -basica-fuerzas-armadas.pdf (Letöltés dátuma: 2020. 11. 05.)

Revista Española de Defensa: Operación Balmis Misión: Salvar vidas. 2020. https://www.defensa.gob.es/Galerias/gabinete/red/2020/05/RED372.pdf (Letöltés dátuma: 2020. 10. 20.)

Revista Española de Defensa: Misión Baluarte: una defensa contra el COVID-19. 2020. https://www.defensa.gob.es/Galerias/gabinete/red/2020/10/p-6-13-red-376-rastreadores.pdf (Letöltés dátuma: 2020. 11. 05.)

Spanish National Security Strategy: 2017. https://www.dsn.gob.es/sites/dsn/files/2017_Spanish_National_Security_Strategy_0.pdf (Letöltés dátuma: 2020. 11. 04.)

Statista: Número total de personas fallecidas a causa del coronavirus en España entre el 6 de marzo y el 4 de diciembre de 2020. 2020. https://es.statista.com/estadisticas/1104277/fallecidos-a-causa-de-covid-19-por-dia-espana/ (Letöltés dátuma: 2020. 12. 07.)

United Nations Security Council Resolution 1325 (2000) on women, peace and security. https://www.un.org/womenwatch/osagi/wps/

World Health Organization: WHO Director-General's opening remarks at the media briefing on COVID-19. 2020.03.11.

https://www.who.int/director-general/speeches/detail/who-director-general-s-opening -remarks-at-the-media-briefing-on-covid-19-11-march-2020 (Letöltés dátuma: 2020. 12. 07.) 